\title{
Variation of major air pollutants in different seasonal conditions in an urban environment in Malaysia
}

\author{
Anis Asma Ahmad Mohtar ${ }^{1}$, Mohd Talib Latif ${ }^{*}$, Nor Hafizah Baharudin ${ }^{1}$, Fatimah Ahamad ${ }^{2}$, Jing Xiang Chung ${ }^{1}$, \\ Murnira Othman ${ }^{1}$ and Liew Juneng ${ }^{1}$
}

\begin{abstract}
Urban air quality has been deteriorating over time. Pollutant distribution levels in the urban environment may be associated with anthropogenic sources and meteorological conditions. The aim of this study is to determine the variation in concentrations of major air pollutants: carbon monoxide $(\mathrm{CO})$, ozone $\left(\mathrm{O}_{3}\right)$, nitrogen dioxide $\left(\mathrm{NO}_{2}\right)$, sulphur dioxide $\left(\mathrm{SO}_{2}\right)$ and particulate matter $\left(\mathrm{PM}_{10}\right)$, with corresponding seasonal variation in a Malaysian urban environment. Eleven years of data from four selected stations, namely Klang (S1), Petaling Jaya (S2), Shah Alam (S3) and Cheras (S4), were analysed for temporal trend variations (yearly and monthly). Statistical analysis using Openair, an R package open source software, has been conducted to assess pollutants in relation to meteorological conditions. Gas concentrations showed little variation between the study sites apart from $\mathrm{NO}_{2}$, which recorded its highest concentrations at an industrial site, between 23 and 40 ppb, and is associated with industrial and vehicle emissions. Pollutants that show seasonal variations and frequently exceed the Malaysia Ambient Air Quality Standard (MAAQS) and the National Ambient Air Quality Standard (NAAQS) are $\mathrm{O}_{3}$ and $\mathrm{PM}_{10}$, predominantly related to the monsoon seasons. High levels of $\mathrm{O}_{3}$ during the northeast monsoon (January-March) are associated with high levels of the precursors of $\mathrm{O}_{3}$. The concentration of $\mathrm{PM}_{10}$ associated with tropical biomass burning during southwest monsoon. Shipping emissions and power stations are main contributors for higher level of $\mathrm{SO}_{2}$. This study shows regional and local factors contribute to the different type of air pollutant concentrations in urban environment.
\end{abstract}

Keywords: Major air pollutants, Urban environment, Air-quality trends, Seasonal variations

\section{Background}

The urban environment experiences high levels of air pollutants in almost all parts of the world. Urban air quality is different in different areas and cities, where the contribution of local sources such as anthropogenic emissions is among the contributing factors (Jang et al. 2017; Nerriere et al. 2005). Large emissions of nitrogen oxides $\left(\mathrm{NO}_{x}\right)$, carbon monoxide $(\mathrm{CO})$ and volatile organic compounds (VOCs) in the urban atmosphere cause high levels of precursors and reactants, with correspondingly large

\footnotetext{
*Correspondence: talib@ukm.edu.my

${ }^{1}$ School of Environmental and Natural Resource Sciences, Faculty of Science and Technology, Universiti Kebangsaan Malaysia, 43600 Bangi, Selangor, Malaysia

Full list of author information is available at the end of the article
}

chemical turnover rates (Monks et al. 2009). According to Fenger (1999), in some cities, increased traffic has produced high emissions of $\mathrm{NO}_{x}$, organic compounds and particles, where photochemical air pollution is a significant problem.

Meteorological factors are key subjects to be studied to understand the variation in air pollutant concentrations and distributions (Wang et al. 2006). Meteorological driving factors are associated with diurnal concentrations of air pollutants, and also influence aerosol composition (Amil et al. 2016; Khan et al. 2016). Variation and trends of pollutants such as $\mathrm{NO}_{x}$, particulates with diameters less than $10 \mu \mathrm{m}\left(\mathrm{PM}_{10}\right)$ and sulphur dioxide $\left(\mathrm{SO}_{2}\right)$ are influenced by land cover and various economies, demographics, and meteorological variables (Rodríguez et al. 2016). A study by Wan 
Mahiyuddin et al. (2013) in Klang Valley, Malaysia, found that there was a relationship between air pollutants and meteorological factors (temperature, rainfall, relative humidity), where the highest significant correlation was between ozone $\left(\mathrm{O}_{3}\right)$ and temperature. Monsoonal winds are also important when investigating the monsoonal effect on atmospheric pollutants, especially for a tropical country such as Malaysia. According to Malaysian Meteorological Department (2017), there are two monsoon seasons in Malaysia, known as the southwest monsoon (June-September) and the northeast monsoon (November-March). Malaysia also experiences transitional wind periods known as inter-monsoons from April to May and October to November.

This study aims to determine the long-term variation in concentrations of major air pollutants along with corresponding seasonal variation at selected airquality monitoring stations in an urban environment in Malaysia. The analysed pollutants were $\mathrm{CO}, \mathrm{O}_{3}$, nitrogen dioxide $\left(\mathrm{NO}_{2}\right), \mathrm{SO}_{2}$ and $\mathrm{PM}_{10}$, using data from an 11-year period to assess the pollutant trends, seasonal effects and exceedance levels at each site. The statistical software Openair R version 3.3.1 (Carslaw and Ropkins 2012) was used to conduct a supplementary analysis to assess concentration distributions in relation to meteorological factors. The results from the analysis are then further discussed in relation to the contribution of local sources to the atmospheric pollutant levels at all study sites.

\section{Methods \\ Study location}

Four continuous air-quality monitoring stations were selected for this study (Fig. 1a, b). Klang (S1), Petaling Jaya (S2), Shah Alam (S3) and Cheras (S4) are located in the Klang Valley, Peninsular Malaysia. The Klang Valley is known as the heartland of Malaysia's industry and commerce, and encompasses Kuala Lumpur, its suburban areas, and adjoining cities and towns. The Klang (S1) and Shah Alam (S3) stations lie in the central region of the Klang Valley. The Klang station (S1) is in the most industrialised area with a congested main road, near to a busy port and power plant (Fig. 1c). The Shah Alam station (S3) is located in a residential and commercial area surrounded by extremely busy motorways. The Petaling Jaya (S2) and Cheras (S4) stations are near to industrial, residential and commercial areas and consequently, congested roads. All stations are also close to the major road to Kuala Lumpur and this is affected by heavy traffic, particularly during the morning rush hour.

\section{Data collection}

Hourly long-term datasets over a period of 11 years from 1st January 2005 to the 31st December 2015 were used a

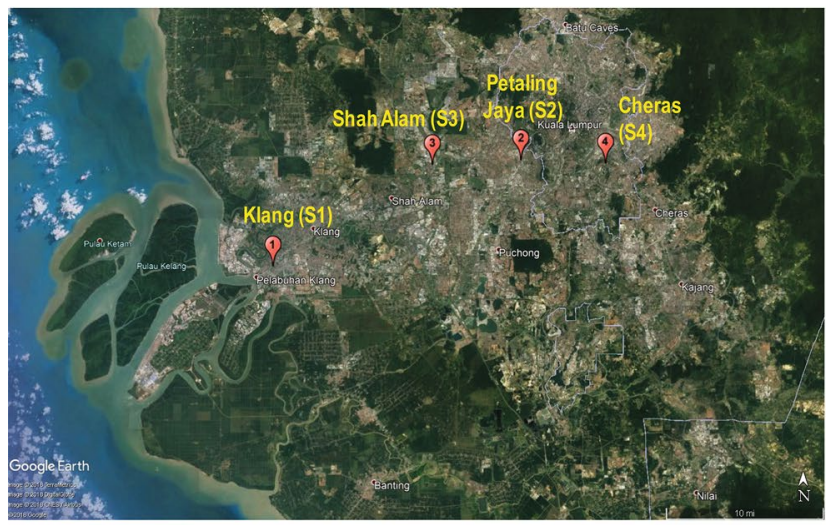



Fig. 1 a Station location of four selected continuous air monitoring stations in urban environment $\mathbf{b}$ Location of selected station situated in Peninsular Malaysia c The white boxes in the figure indicate industrial areas surrounding Klang Station 
in this study for all stations. Air-quality data along with meteorological data in this study were retrieved from the Malaysian Department of Environment through continuous air monitoring by a private company Alam Sekitar Sdn. Bhd. (ASMA) who were also responsible for calibrating the equipment. Air pollutant parameters used in this study are $\mathrm{CO}(\mathrm{ppm}), \mathrm{NO}_{2}(\mathrm{ppb}), \mathrm{SO}_{2}(\mathrm{ppb}), \mathrm{O}_{3}(\mathrm{ppb})$ and $\mathrm{PM}_{10}\left(\mu \mathrm{g} / \mathrm{m}^{3}\right)$. In addition, the local meteorological parameters used in this study such as wind speed $(\mathrm{km} / \mathrm{h})$ and wind direction were also recorded at the stations.

\section{Data analysis}

Time series data of air pollutants at the stations were analysed to study the spatial and temporal variation of air pollutants at four study locations. To study the trend of air pollutants for the study period, monthly mean values were calculated by averaging hourly concentration measurements. The data were smoothed using Locally Weighted Scatterplot Smoothing (LOESS). This method was used to visually examine the non-linearity of trends (Jang et al. 2017). Annual mean concentrations were calculated by averaging hourly values of each year and normalised to the mean concentration of 2005 to investigate the long-term pollution trend.

Daily maximum concentration of pollutants with respect to averaging hour of the Malaysian Ambient Air Quality Standard (MAAQS) and the National Ambient Air Quality Standard (NAAQS) of the United States Environmental Protection Agency (USEPA) were calculated and plotted to study the exceedance level of pollutants during the study period. Running average data for $\mathrm{O}_{3}$ were $8 \mathrm{~h}$ and $\mathrm{PM}_{10}$ were $24 \mathrm{~h}$ while $\mathrm{CO}, \mathrm{NO}_{2}$ and $\mathrm{SO}_{2}$ were $1 \mathrm{~h}$. The running times for different air pollutants were based on averaging times suggested by MAAQS and NAAQS of USEPA. In addition, wind speed, wind direction and air pollutant data were computed and analysed using statistical software Openair, $\mathrm{R}$ package version 3.3.1 (Carslaw 2015) which can be downloaded free from the website http://www.openair-project.org/.

\section{Results and discussion}

\section{Trends and spatial variability in urban environment}

The plots in Fig. 2a-e show the monthly mean concentrations of air pollutants and the estimated trend for the 11 years from January 2005 to December 2015. Figure $2 \mathrm{f}-\mathrm{j}$ shows the normalised annual mean of air pollutants with respect to annual mean value of 2005 to estimate the annual trend. Higher concentrations of $\mathrm{CO}$ can be seen at $\mathrm{S} 2$ which has an industrial background compared to the other three urban background sites (Fig. 2a) but CO levels for S2 declined from 2007 onwards. All stations experienced the same pattern in $\mathrm{CO}$ in the second half of the 2015 due to biomass burning during September and October, leading to a severe haze episode in Malaysia (Field et al. 2016; Shannon et al. 2016; Tacconi 2016). S2 had high concentrations of CO, likely to be due to the incomplete combustion of fossil fuel from industrial sectors (Khan et al. 2015). The normalised plot in Fig. $2 \mathrm{f}$ indicates that $\mathrm{CO}$ annual levels for S2, S3 and S4 were not significantly different from each other; however, $\mathrm{S} 1$ experienced a drop in $\mathrm{CO}$ from 2012 to 2015 with values of $1.21-0.89 \mathrm{ppm}$. The reduction of yearly $\mathrm{CO}$ concentrations is mostly due to the reduction of regional biomass-burning occurrences after 2007. Other than motor vehicles and industrial activities, incomplete combustion of biomass contributes to high amounts of $\mathrm{CO}$ as well as particulate matter (Latif et al. 2018).

Monthly mean concentrations for $\mathrm{O}_{3}$ showed (Fig. 2b) almost the same pattern for all stations, where $\mathrm{S} 3$ showed the highest concentrations until 2010 when this changed to S4. S3 and S4 recorded high concentrations of $\mathrm{O}_{3}$ because these stations had low NO levels, meaning the interaction between $\mathrm{NO}$ and $\mathrm{O}_{3}$ via the titration process was less, thus leaving the $\mathrm{O}_{3}$ level higher compared to $\mathrm{S} 1$ and S2. S1 and S2 are located in the city centre in busy locations, leading to higher levels of NO that can titrate $\mathrm{O}_{3}$ and, therefore, reduce the concentration (Banan et al. 2013; Latif et al. 2012; Wang et al. 2017). In general, the $\mathrm{O}_{3}$ pattern for all stations showed an increase over the 11-year time period, despite slight decreases. As seen in Fig. 2g, S1 showed a significant decrease in $\mathrm{O}_{3}$ from 2009 to 2013 (20.27-17.21 ppb) which may be due to its geographic location as S1 is close to the shipping port and main roads. Increase in traffic and shipping activities over a decade is expected to result in increasing $\mathrm{NO}$ concentrations and subsequent decreasing $\mathrm{O}_{3}$ trends due to the ability of $\mathrm{NO}$ to titrate $\mathrm{O}_{3}$ (Song et al. 2010). Continuous higher concentrations of $\mathrm{NO}$ have decreased the long-term concentrations of $\mathrm{O}_{3}$ in this area.

The $\mathrm{NO}_{2}$ concentrations presented marked spatial variability for S2 as shown in Fig. 2c and Additional file 1 . This site with an industrial background showed higher concentrations of $\mathrm{NO}_{2}$ compared to urban sites of S1, S3 and S4. S2 is an industrial site and there are residential areas near S2 that may increase the $\mathrm{NO}_{2}$ levels coming from both industrial emissions and residential areas with high vehicle use. According to Dominick et al. (2012), $\mathrm{NO}_{2}$ levels recorded in industrial and urban environments are high because of the burning of fossil fuels. Based on Fig. 2a, c, the distribution of $\mathrm{CO}$ and $\mathrm{NO}_{2}$ among the study sites was almost the same, with $\mathrm{S} 2$ taking the lead in the concentrations of pollutants. Both $\mathrm{CO}$ and $\mathrm{NO}_{2}$ are primary pollutants that are mainly emitted from motor vehicles (Azmi et al. 2010; Dor et al. 1995; Mayer 1999; Morawska et al. 2002). Normalised annual 

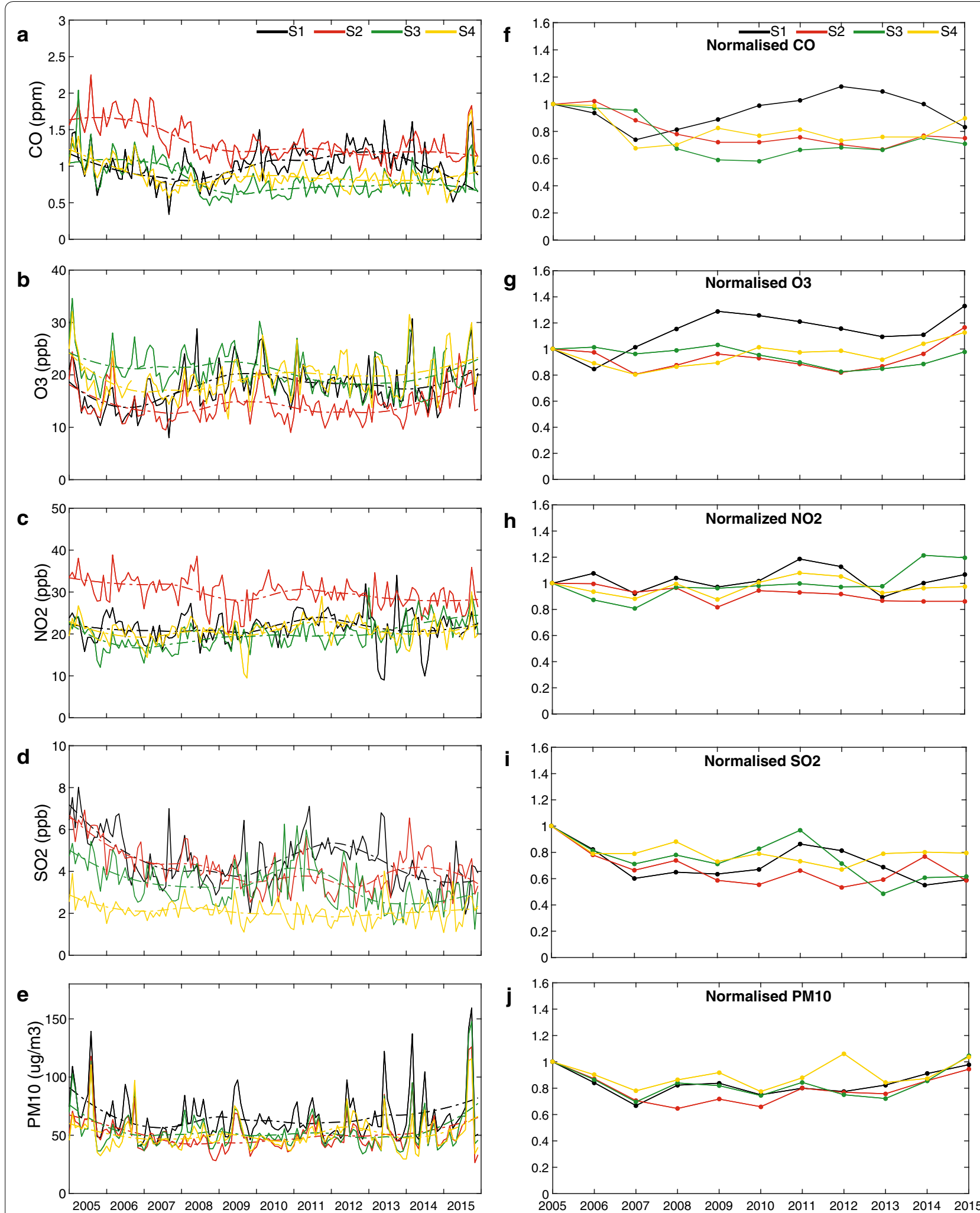

Fig. 2 Monthly mean concentrations with smoothing lines indicate trend of $\mathbf{a} \mathrm{CO}_{\mathbf{b ~ O}} \mathbf{c ~ N O}_{2} \mathbf{d ~ S O} \mathrm{SO}_{2}$ e $\mathrm{PM}_{10}$ between 2005 and 2015 and annual trend of $\mathbf{f} \mathrm{CO}_{\mathbf{g ~ O}} \mathbf{h} \mathrm{hO}_{2} \mathbf{i} \mathrm{SO}_{2} \mathbf{j} \mathrm{PM}_{10}$ concentration normalised to annual mean of 2005 
concentrations in Fig. 2h showed no significant longterm trends in $\mathrm{NO}_{2}$ levels for all sites.

The long-term trends of $\mathrm{SO}_{2}$ at $\mathrm{S} 1$ and $\mathrm{S} 3$ have similar patterns (Fig. 2d, i) with decreased $\mathrm{SO}_{2}$ levels until 2007 before it continued to elevate until 2011. S2 showed similar patterns and concentrations to S1 and S3 as they are located near each other. Emissions from shipping are the reason why $\mathrm{S} 1$ had high $\mathrm{SO}_{2}$ concentrations because the station is near to a shipping port. However, normalised plots for $\mathrm{SO}_{2}$ (Fig. 2i) indicated that in general, all stations experienced decreased $\mathrm{SO}_{2}$ level from 2005 to 2015. Overall, the reduction of $\mathrm{SO}_{2}$ is due to the reduction of sulphur content in petrol and diesel as indicated by other similar research (Blumberg et al. 2003; Guarieiro and Guarieiro 2013; Lamarque et al. 2010). The fluctuations of $\mathrm{SO}_{2}$ in the study area may due to the contributions of $\mathrm{SO}_{2}$ from local and regional sources of biomass burning.

Interestingly, all stations displayed the same pattern with almost the same peak and monthly mean for $\mathrm{PM}_{10}$ concentrations (Fig. 2e). This is because when the west coast of Peninsular Malaysia encounters transboundary haze pollution episodes, all those stations will be affected as they are located in the central region of the west coast (Awang et al. 2000; Azmi et al. 2010; Hyer and Chew 2010; Juneng et al. 2009; Khan et al. 2015; Lin et al. 2009). $\mathrm{PM}_{10}$ is the main parameter during haze and is decisive in the calculation of the Malaysian Air Pollution Index (Afroz et al. 2003). During haze episode, the smoke from Sumatra will travel to the Peninsular Malaysia. In most cases, all the stations located on the west coast of Peninsular Malaysia have similar patterns of $\mathrm{PM}_{10}$ concentration during the haze episode based on the intensity of the smoke and wind direction. The haze peak can be seen in almost every year except 2007 and 2010. In 2007 and 2010, there were no regional biomass-burning episodes to contribute to the high concentration of $\mathrm{PM}_{10}$. In addition to that, an article by Latif et al. (2018) showed that 2007 and 2010 were non-El Niño years and so lower concentrations of $\mathrm{PM}_{10}$ were recorded at the study sites. The monthly concentrations were highest in 2015 and followed by 2005 because in these years there were El Niño events that triggered the haze with dry conditions, thus prolonging the drought and intensifying forest fires (Aouizerats et al. 2015; Field et al. 2016; Shannon et al. 2016; Tangang et al. 2010). The intensity of combustion and haze episodes was influenced by dry weather conditions. A strong El Niño event influences regional wind circulation and causes prolonged dry conditions in Southeast Asia. The dry conditions lead to severe haze episodes, particularly due to combustion activities and especially within peat soil areas (Reid et al. 2012). The annual mean concentrations of $\mathrm{PM}_{10}$ (Additional file 1) reveal fluctuations over the years with peaks that correspond to haze and El Niño events. S4 showed a sudden increase in 2012 (Fig. 2j) that might be due to emissions from local sources such as open burning and land use changes near the site that contributed to the $\mathrm{PM}_{10}$ level (Khan et al. 2015).

The annual mean concentrations of each pollutant from 2005 to 2015 are summarised in Additional file 1 . In general, averages of the annual means from 2005 to 2015 showed that S2 recorded the highest concentration of CO (1.34 ppm) compared to S1 (1.02 ppm), S4 $(0.88 \mathrm{ppm})$ and $\mathrm{S} 3(0.82 \mathrm{ppm})$. This is likely to be because $\mathrm{S} 2$ is located in an industrial area with high traffic emissions. Average annual concentrations of $\mathrm{O}_{3}$ indicated that S3 experienced high levels with $20.61 \mathrm{ppb}$, followed by S4 (19.60 ppb), S1 (17.81 ppb) and S2 (14.32 ppb). For $\mathrm{NO}_{2}, \mathrm{~S} 2$ as the industrial site revealed the highest average during the study period, followed by S1, S4 and S3 with concentrations of $\mathrm{NO}_{2}$ of $29.86 \mathrm{ppb}, 21.43 \mathrm{ppb}, 20.74 \mathrm{ppb}$ and $19.80 \mathrm{ppb}$, respectively. In addition, $\mathrm{S} 1$ revealed the highest average annual mean of $\mathrm{SO}_{2}$ with $4.48 \mathrm{ppb}$, followed by S2 (4.16 ppb), S3 (3.38 ppb), and S4 (2.10 ppb). $\mathrm{S} 1$ recorded high concentrations as the location of $\mathrm{S} 1$ is near to the shipping port, where emissions of $\mathrm{SO}_{2}$ and $\mathrm{NO}_{2}$ are high. For $\mathrm{PM}_{10}$, S1 had the highest average annual mean concentration with $65.86 \mu \mathrm{g} / \mathrm{m}^{3}$ followed by S3 $\left(53.76 \mu \mathrm{g} / \mathrm{m}^{3}\right), \mathrm{S} 2\left(50.89 \mu \mathrm{g} / \mathrm{m}^{3}\right)$ and last S4 $(50.75 \mu \mathrm{g} /$ $\left.\mathrm{m}^{3}\right)$.

\section{Exceedance levels of air pollutants}

Figure 3 shows the daily maximum concentration of trace species from 2005 until 2015 with respect to their averaging time. The averaging time for exceedance levels for $\mathrm{CO}, \mathrm{NO}_{2}$ and $\mathrm{SO}_{2}$ was $1 \mathrm{~h}$, for $\mathrm{O}_{3}$ it was $8 \mathrm{~h}$ and for $\mathrm{PM}_{10}$ $24 \mathrm{~h}$. The exceedance levels of pollutants were compared with the NAAQS and the MAAQS which can be seen in Additional file 2. In general, there were two pollutants $\left(\mathrm{O}_{3}\right.$ and $\left.\mathrm{PM}_{10}\right)$ that abundantly exceeded both NAAQS and MAAQS (Fig. 3b, e).

The exceedance level recorded for $\mathrm{O}_{3}$ (Fig. 3b) was quite high in number for all four stations in every year, especially during the first quarter of the year. The concentrations of $\mathrm{O}_{3}$ for the $8 \mathrm{~h}$ average exceeded both the NAAQS $(70 \mathrm{ppb})$ and the MAAQS $(60 \mathrm{ppb})$. The number of $\mathrm{O}_{3}$ exceedance events around Klang Valley can be seen from a study by Ahamad et al. (2014), where it was concluded that $\mathrm{O}_{3}$ exceedance patterns were greatly influenced by localised pollutant emissions. According to a study by Latif et al. (2012), S1 located near the sea and the shipping port may be influenced by sea breezes causing the dispersion of pollutants. In addition to that, $\mathrm{S} 3$ and $\mathrm{S} 4$ had high $\mathrm{O}_{3}$ concentrations due to local conditions while $\mathrm{S} 2$ had the lowest exceedance due to the titration process of $\mathrm{O}_{3}$ by $\mathrm{NO}$. 

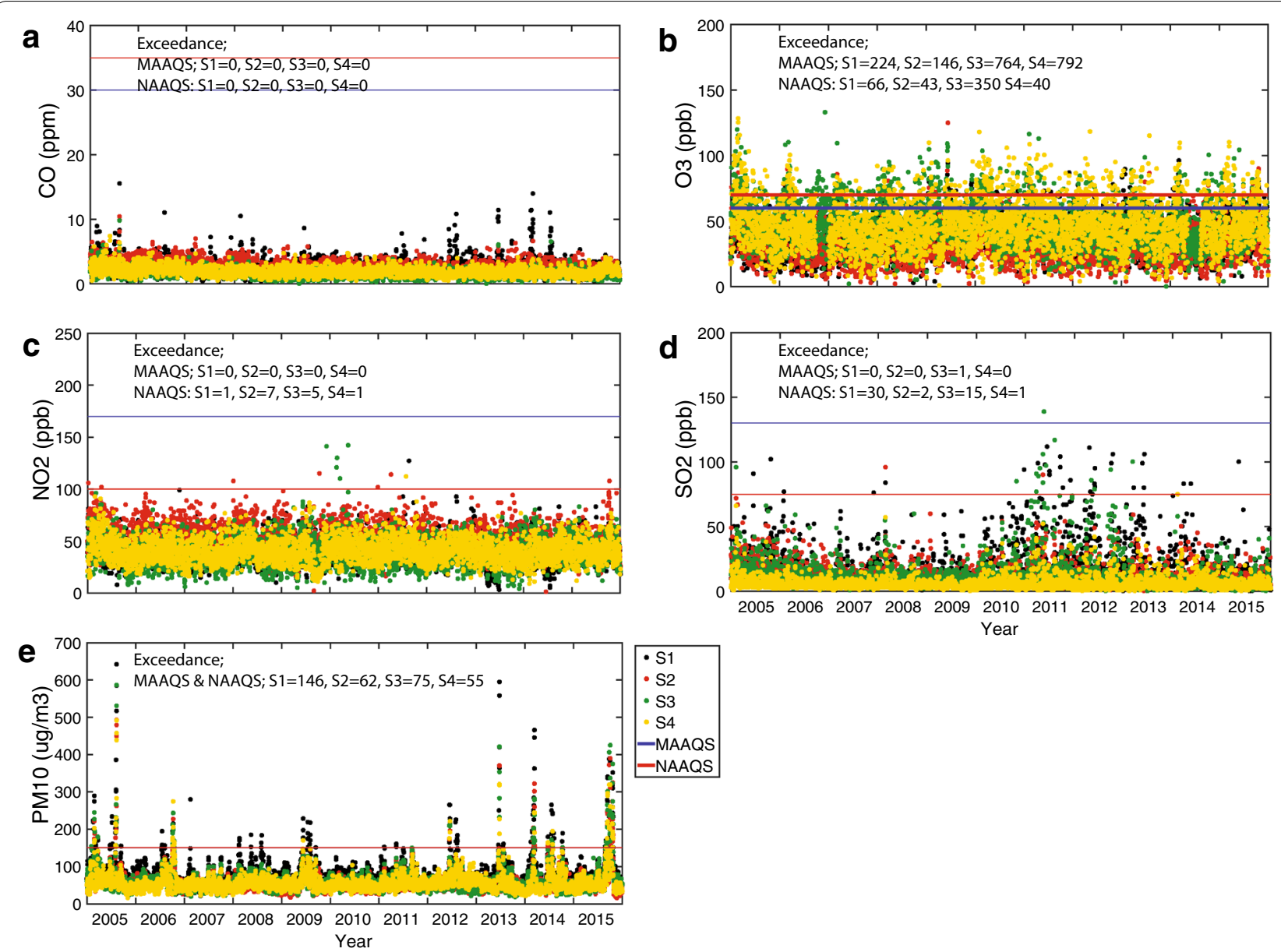

Fig. 3 Daily exceedance level of air pollutants ( $\mathbf{a} \mathrm{CO}_{\mathbf{b ~ O}} \mathbf{c ~ N O}_{2} \mathbf{d ~ S O} \mathrm{SO}_{2}$ e $\mathrm{PM}_{10}$ ) between 2005 and 2015 with respect to averaging time according to Malaysia Ambient Air Quality Standard (MAAQS) and USEPA National Ambient Air Quality Standard (NAAQS). The total occurrence of daily exceedance is stated in the figure for 2005-2015

Both the NAAQS and the MAAQS for $\mathrm{PM}_{10}$ are $150 \mu \mathrm{g} / \mathrm{m}^{3}$. As shown in Fig. 3e, the exceedance level of $\mathrm{PM}_{10}$ can be seen for almost every year except in 2007 and 2010 for all stations. The highest exceedance level recorded for $\mathrm{PM}_{10}$ was in mid-2005 and mid-2013 (less than $700 \mu \mathrm{g} / \mathrm{m}^{3}$ ) at $\mathrm{S} 1$. In addition to that, there were episodes where $\mathrm{PM}_{10}$ levels were high for several days to weeks, for example, in 2005, 2006, 2008, 2009, 2012, 2014 and 2015. A study by Rahman et al. (2015) stated that S1 had the highest number of exceedance events compared to S2, S3 and S4, and these were related to severe haze episodes that transported suspended particulates from Sumatra to the west coast of Peninsular Malaysia.

\section{Monthly variation of air pollutants}

Daily mean concentrations of air pollutants were calculated using data measurements from January 2005 to December 2015. Monthly variations shown in Fig. 4 are presented as the number of days from January 1 with a total of 365 data points. Daily mean concentrations for CO (Fig. 4a) were almost consistent throughout the months for S1, S3 and S4 but not for S2, which had slightly higher $\mathrm{CO}$ levels but with the same pattern concentration distribution. The highest $\mathrm{CO}$ concentrations were recorded at $\mathrm{S} 2$ with the range of between 1.0 and $2.0 \mathrm{ppm}$ during the northeast monsoon (NovemberMarch), while during the southwest monsoon (June-September), $\mathrm{CO}$ concentrations were recorded between 1.0 and $1.6 \mathrm{ppm}$. The CO monthly trend showed less seasonal influence compared to other pollutants. Emissions from motor vehicles dominated the source of $\mathrm{CO}$ compared to other potential sources including biomass burning and industrial activities (Streets et al. 2003; Zhang et al. 2009).

The $\mathrm{O}_{3}$ concentrations clearly showed the monsoonal effect on $\mathrm{O}_{3}$ distributions (Fig. 4b). Higher $\mathrm{O}_{3}$ levels presented from January to March while the lowest $\mathrm{O}_{3}$ levels were in July to August. A study by Latif et al. 

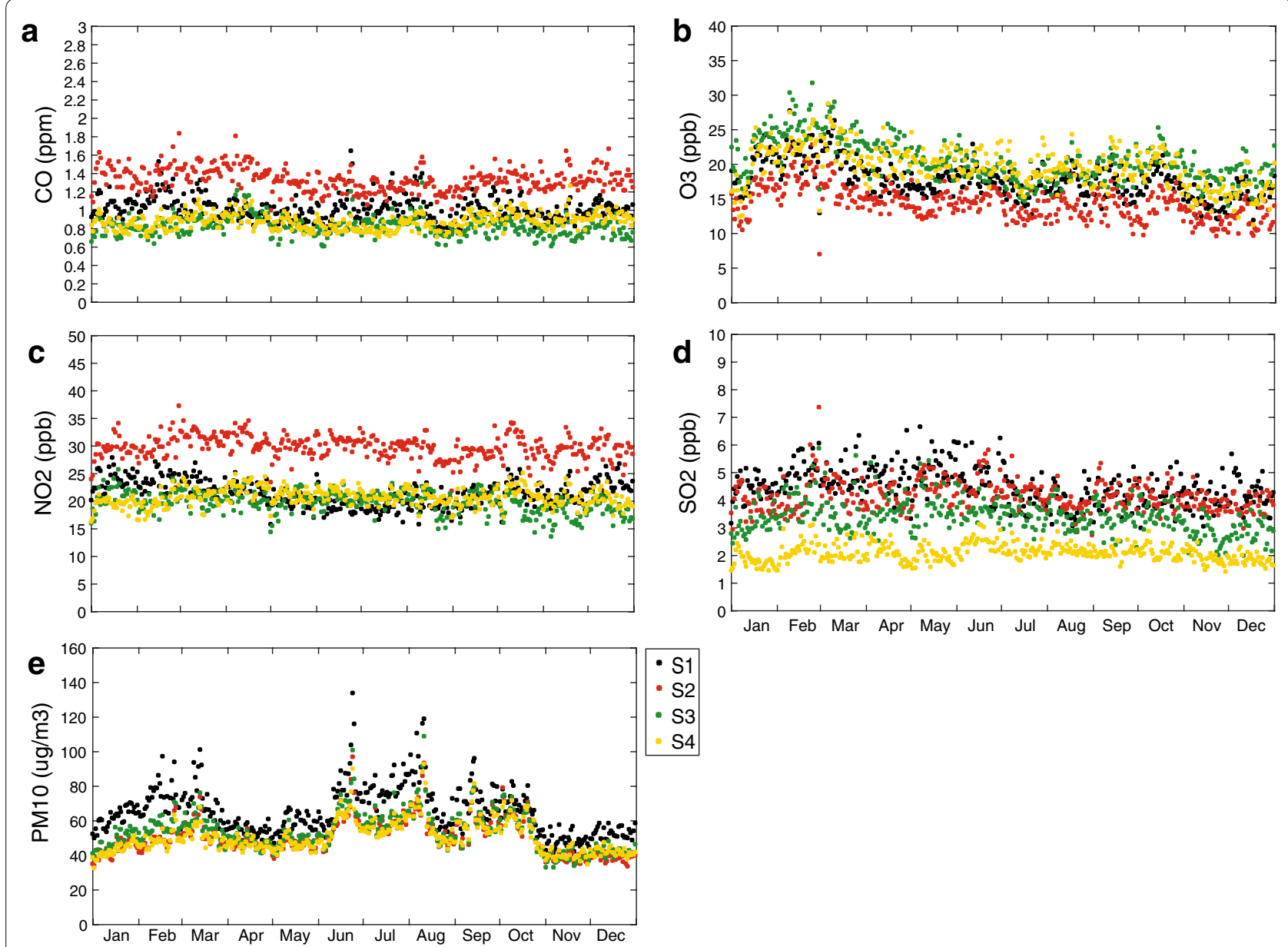

Fig. 4 Monthly variability of daily mean concentration for a $\mathrm{CO}_{\mathbf{b ~ O}} \mathbf{c} \mathrm{cNO}_{2} \mathbf{d ~ S O} \mathrm{SO}_{2}$ e $\mathrm{PM}_{10}$ concentration from 2005 to 2015

(2012) showed the same result as this study, where $\mathrm{O}_{3}$ concentrations were high between January and April as the winter monsoon brings pollutants from the area to the northeast of the Malaysian Peninsula including Indochina and the South China Sea. In addition to that, Yonemura et al. (2002) stated that the enhancement of $\mathrm{O}_{3}$ during December-February in the middle troposphere probably originates from the deep convection of air masses because of the positive temperature anomaly with a negative water vapour anomaly. According to Yamaji et al. (2006), low production of $\mathrm{O}_{3}$ during the summer monsoon is probably associated with the incursion of monsoon oceanic air carrying less $\mathrm{O}_{3}$ to the region. Other than that, precipitation will have a washout effect towards pollutants in the air and thus reduce the level of pollutants in the atmosphere (Yoo et al. 2014). However, according to Rahman et al. (2015), high levels of pollutants during this season may not be associated with meteorological factors but are more associated with local environmental factors, for example, emissions from industries, urbanization and motor vehicles.

Figure $4 \mathrm{c}$ shows the monthly variation of $\mathrm{NO}_{2}$ concentrations and the trend is similar to that of $\mathrm{CO}$ (Fig. 4a). The industrial site $\mathrm{S} 2$ recorded high concentrations of $\mathrm{NO}_{2}$ in all months but with a consistent trend, and a similar trend was recorded for $\mathrm{S} 1, \mathrm{~S} 3$ and $\mathrm{S} 4$. The $\mathrm{NO}_{2}$ concentrations recorded at $\mathrm{S} 2$ during the northeast monsoon (November-March) were between 23 and $40 \mathrm{ppb}$, while during the southwest monsoon (June-September), $\mathrm{NO}_{2}$ concentrations were recorded between 20 and 35 ppb. Industrial emissions and urban road traffic are the main contributors to the higher concentrations of $\mathrm{NO}_{2}$ at $\mathrm{S} 2$ compared to the other sites. Other than that, the distribution of monthly $\mathrm{SO}_{2}$ concentrations (Fig. 4d) was scattered and had large ranges even in the same month and same monsoon period. Only S4 exhibited consistent concentrations that did not differ much across the months. The higher ranges of $\mathrm{SO}_{2}$ recorded at $\mathrm{S} 1, \mathrm{~S} 2$ and $\mathrm{S} 3$ are due to their locations near to potential sources such as a 
shipping port, a coal-fired power plant (S1) and industrial activities (S1, S2, S3). S4 is located in a residential area which is only influenced by motor vehicles as $\mathrm{SO}_{2}$ contributors. The main sources of $\mathrm{SO}_{2}$ are from burning of fossil fuel at power plants and industrial facilities (Butler and Whelan 2018; Pereira et al. 2007; Streets and Waldhoff 2000). Based on the Fig. 4c, d, the concentrations of $\mathrm{NO}_{2}$ and $\mathrm{SO}_{2}$ showed less monsoonal effects compared to other pollutants $\left(\mathrm{O}_{3}\right.$ and $\left.\mathrm{PM}_{10}\right)$.

The monsoonal effect can easily be detected for $\mathrm{PM}_{10}$ distributions as all stations revealed the same patterns, with the highest concentrations at S1 followed by S3, S2 and S4 (Fig. 4e). The peak $\mathrm{PM}_{10}$ levels can be seen in February, March, June, August, September and October. In addition to that, peak $\mathrm{PM}_{10}$ levels were high mostly during June-September, which is during the southwest monsoon (Aouizerats et al. 2015; Heil and Goldammer 2001; Keywood et al. 2003; Khan et al. 2015; Kusumaningtyas and Aldrian 2016; Noor et al. 2015; Rahman et al. 2015; Shannon et al. 2016; Tangang et al. 2010), where low-level winds were associated with long-range transportation of pollutants (Khan et al. 2015; Lee et al. 2017; Noor et al. 2015). Besides, there are several factors that influence $\mathrm{PM}_{10}$ variations during summer monsoons and dry seasons. According to Juneng et al. (2011), these factors can be categorised into three groups, namely local meteorological factors, synoptic weather conditions, and hotspot number counts that represent regional emission conditions. The local meteorological factors that affect $\mathrm{PM}_{10}$ variation during the summer monsoon are surface air temperature, humidity and wind speed. In our region, the day-to-day variation of aerosol is pretty much modulated by the synoptic circulation which controls the regional moisture convergence and divergence. So, cyclones over the Western North Pacific draw much of the moisture away from Malaysia and elevate the risk of higher air pollution. The number of hotspots represents the numbers of biomass-burning locations based on identification from satellite images. Higher numbers of hotspots contribute high concentrations of smoke that is then transported to the downwind area which is determined by the wind direction.

\section{Meteorological conditions effects on spatial and temporal variability}

The compilation of processed data from the different study sites showed variability in both the levels of pollution and the long-term trends of air pollutants. Temporal variability of air pollutant concentrations from 2005 to 2015 leads to the study of local meteorological effects on the concentrations of air pollutants. Subsequently, from previous sections of site-specific temporal variability data, this study specifically focused on three significant issues: (1) monthly mean trends showed high concentrations of $\mathrm{NO}_{2}$ at $\mathrm{S} 2$ (Fig. 2c) compared to the other sites; (2) the trend of normalised mean concentrations marked a reduction in $\mathrm{O}_{3}$ levels at $\mathrm{S} 1$ (Fig. 2g) after a spike in concentrations in 2009; (3) the concentrations of $\mathrm{SO}_{2}$ for the monthly variation plot were particularly scattered and enhanced at certain times for S1 (Fig. 4d).

High concentrations of $\mathrm{NO}_{2}$ at $\mathrm{S} 2$ (the industrial site) prompted further study of temporal variations and local meteorological effects towards $\mathrm{NO}_{2}$ levels as shown in Fig. 5. Based on Fig. 5a, the diurnal pattern of $\mathrm{NO}_{2}$ concentrations had two peaks, one in the morning around 9 am and one in the evening at around $7 \mathrm{pm}$. Both of these times were during rush hour where people use motor vehicles to travel to and from their workplace. This situation coincides with weekly pattern with higher concentrations on weekdays but not at the weekend. Figure 5b, c shows bivariate polar annulus functions in both monthly and trend variations. Bivariate polar annulus functions can examine the temporal aspects of pollutant concentrations by wind direction. Figure $5 \mathrm{~b}$, c exhibits higher $\mathrm{NO}_{2}$ concentrations dominated by south-westerly winds especially in February-March and June-July. The concentrations of $\mathrm{NO}_{2}$ are likely to be affected by local vehicle emissions from major roads.

The trend of normalised mean concentrations marked a reduction in $\mathrm{O}_{3}$ levels at $\mathrm{S} 1$ (Fig. $2 \mathrm{~g}$ ) and leads to the study between the lower $\mathrm{O}_{3}$ period (2005-2009) and higher $\mathrm{O}_{3}$ period (2010-2015). The temporal patterns of $\mathrm{O}_{3}$ concentrations and meteorological variations between 2005 and 2009, and 2010-2015 at S1 are shown in Fig. 6. In 2010-2015, the mean hourly $\mathrm{O}_{3}$ concentrations were slightly higher compared to 2005-2009 with the peak hour at 2.00 p.m. (Fig. 6a). A study by Azmi et al. (2010) experienced the same result for S1 where sunlight had enhanced the formation of $\mathrm{O}_{3}$. Corresponding to the diurnal plot, the weekly plot (Fig. 6b) also indicated higher mean $\mathrm{O}_{3}$ concentrations in 2010-2015 compared to 2005-2009. The weekly plot showed no significant difference. As shown in Fig. 6c, the monthly variations of $\mathrm{O}_{3}$ levels in 2005-2009 showed the highest concentrations in January to March, dominated by westerly winds. The concentrations in 2010-2015 were enhanced from previous years and presented enhancement in June-September with south-westerly winds. Besides, January-April in 2010-2015 (Fig. 6d) showed an enhancement in concentrations with the domination of westerly winds. A study 


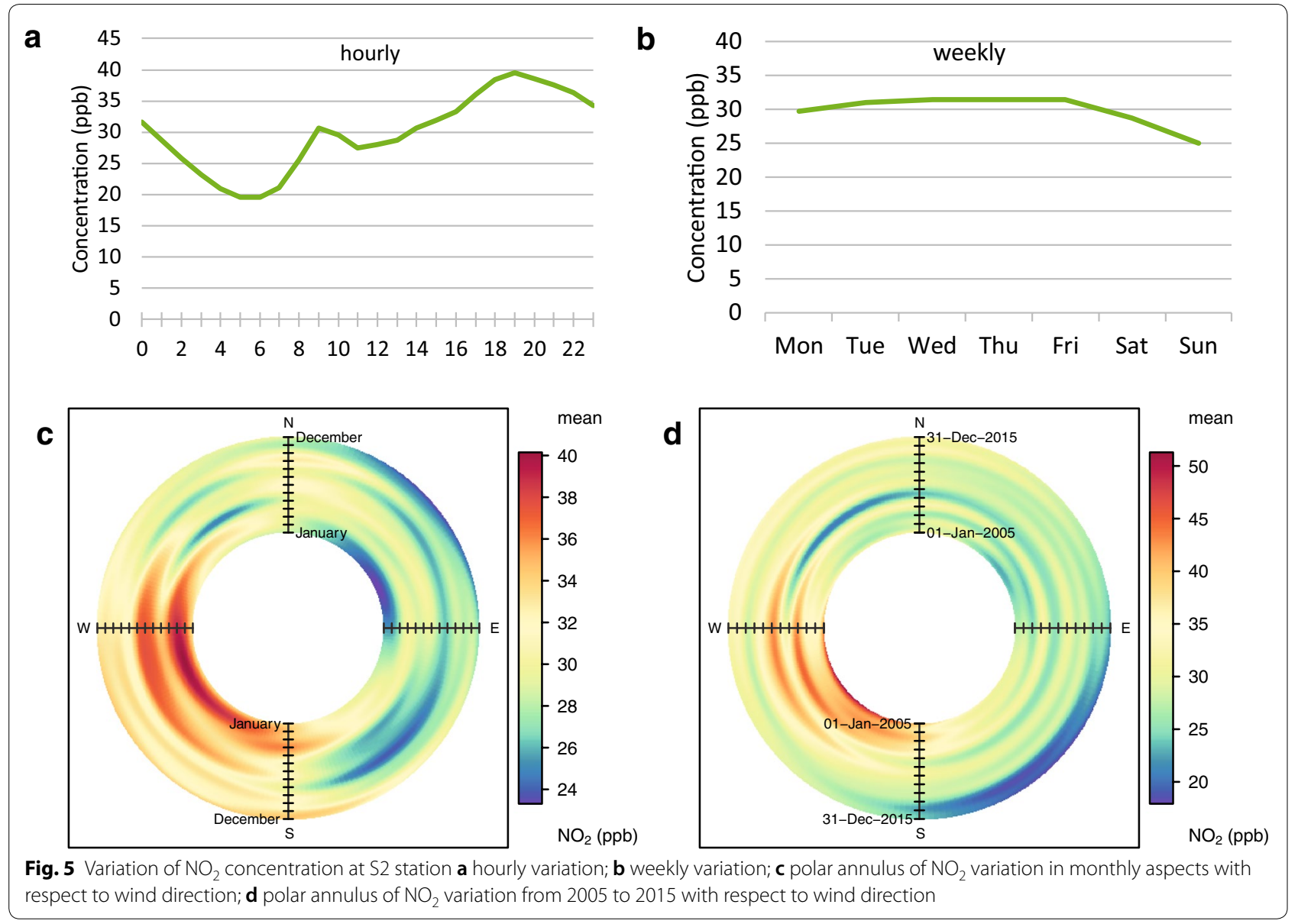

by Latif et al. (2018) showed that the seasonal $\mathrm{O}_{3}$ distribution was influenced by the seasonal wind direction and locations of study sites. In that study, January-April also known as the winter monsoon-spring transitional season recorded the maximum distribution of $\mathrm{O}_{3}$ concentrations in city centre. This is because the advecting of $\mathrm{O}_{3}$ precursors to the sampling site thus contributed to the high amount of $\mathrm{O}_{3}$ concentrations.

The scattered and enhanced concentrations of $\mathrm{SO}_{2}$ in monthly variation plot lead to the study between concentration of $\mathrm{SO}_{2}$, wind speed and wind direction. The hourly mean $\mathrm{SO}_{2}$ concentrations as a function of wind speed and wind direction differed between the months (Fig. 7a). Concentrations of $\mathrm{SO}_{2}$ were highest in May and associated with north-westerly winds with relatively low wind speed $(10-15 \mathrm{~km} / \mathrm{h})$ while the lowest contributions were in July and August. Generally, the monthly $\mathrm{SO}_{2}$ distribution observed was high during low-speed north-westerly winds. Figure $7 \mathrm{~b}$ presents a percentile rose plot that calculated the $\mathrm{SO}_{2}$ percentile levels and plots by wind direction. This plot is useful in determining the $\mathrm{SO}_{2}$ concentration distributions by wind direction and reveals various sources. In this case, during May which recorded the highest mean concentration, $\mathrm{SO}_{2}$ distributions had consistent groups of percentiles from 75th to 85th, 85th to 95th, 95th to 99th and 99th to 99.9th that experienced north-westerly winds. This can bring high concentrations of $\mathrm{SO}_{2}$ towards the site as there is an industrial area, shipping port and coal-fired power plant from the northwest of S1 as seen in Fig. 1c (North Port Klang). Distributions of $\mathrm{SO}_{2}$ by winds in July and August were lowest compared to the other months and the concentrations recorded were also the lowest in both months. In July, the distribution of $\mathrm{SO}_{2}$ was dominated by south-westerly and northerly winds that likely brought $\mathrm{SO}_{2}$ originating from the shipping port (West Port Klang) 

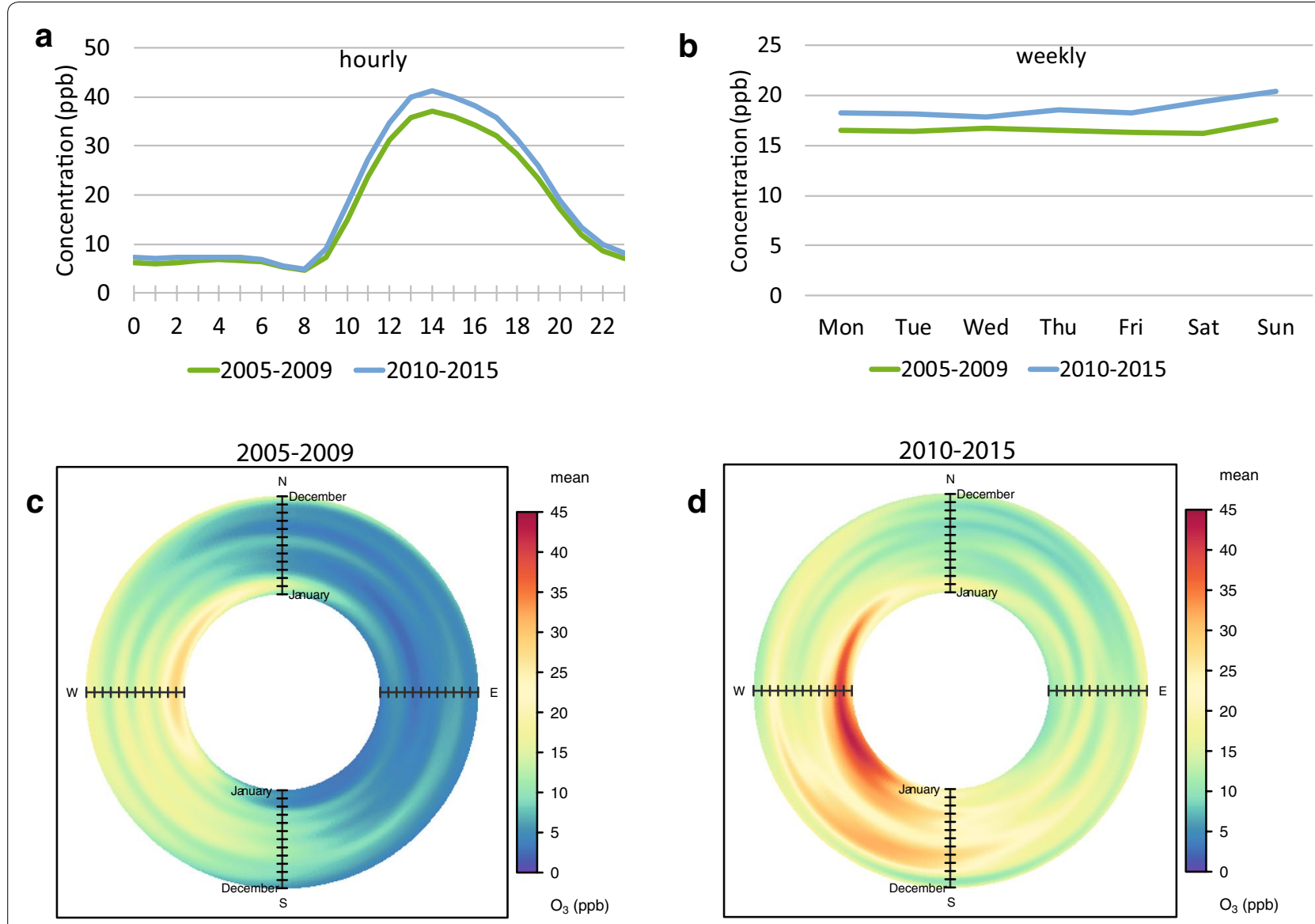

Fig. 6 Comparison of lower $\mathrm{O}_{3}$ period (2005-2009) and higher $\mathrm{O}_{3}$ period (2010-2015) at S1 station. a Hourly variability; b weekly variability; c monthly variation of bivariate polar annulus plot for lower $\mathrm{O}_{3}$ period and $\mathbf{d}$ for higher $\mathrm{O}_{3}$ period

and vehicles from the residential area, respectively. However, for August, the 99th-99.99th percentile concentrations (40-60 ppb) were associated with north-westerly winds that estimated to come from the shipping port, North Port Klang and coal-fired power plant direction. From Fig. 7b, it can be concluded that most 99th-99.99th percentile concentrations in every month were correlated with north-westerly wind and south-westerly winds that expected comprised high $\mathrm{SO}_{2}$ levels coming from the shipping port and power plants. The $\mathrm{SO}_{2}$ distributions may also be related to emissions from road traffic as $\mathrm{S} 1$ is located near a residential area.

\section{Conclusion}

The results of this study showed that the application of time series plots can give information on the temporal trends of pollutants at specific study sites. The study revealed that gas concentrations in the Malaysian urban environment did not fluctuate between each site, except for $\mathrm{NO}_{2}$ with the highest levels recorded at the industrial site S1, ranging between 23 and $40 \mathrm{ppb}$. In general, $\mathrm{CO}$ levels are affected by vehicle emissions while $\mathrm{NO}_{2}$ levels are affected by both vehicle and industrial emissions. Precursors of $\mathrm{O}_{3}$ such as $\mathrm{NO}_{x}$ determined the level of $\mathrm{O}_{3}$ at the different background sites while factors that affected $\mathrm{SO}_{2}$ distribution levels were related to industrial, shipping and power plant emissions. Other than that, concentrations of $\mathrm{PM}_{10}$ were strongly associated with monsoonal effects that bring pollutants from biomass burning. $\mathrm{O}_{3}$ and $\mathrm{PM}_{10}$ showed frequent exceedance of both MAAQS and NAAQS. In addition, these two parameters were also found to be influenced by monsoon seasons.

Local source emissions of pollutants can be identified from the statistical analysis of concentrations with meteorological factors that are imperceptible in a general temporal plot. The pattern of wind direction and $\mathrm{NO}_{2}$ concentrations showed that the main contributor 


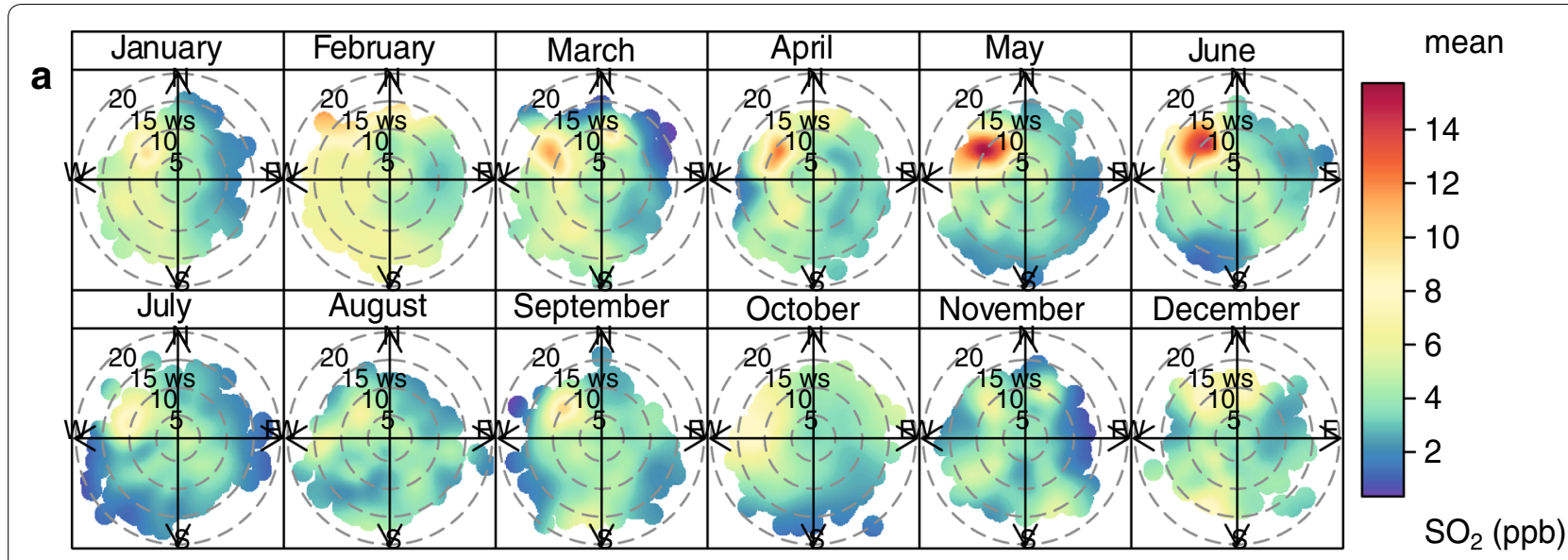

b

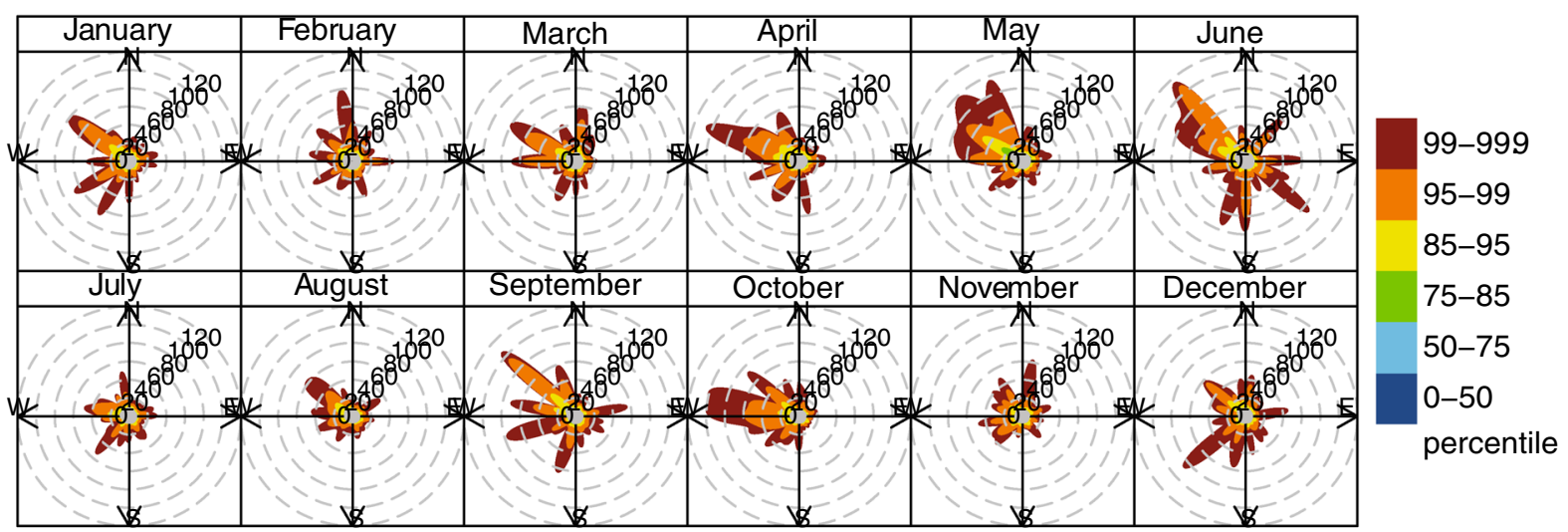

Fig. 7 Bivariate polar plot and percentile rose plot of $\mathrm{SO}_{2}$ concentrations (ppb) at $\mathrm{S} 1$ station; a bivariate polar plot of $\mathrm{SO}_{2}$ concentration with wind speed and wind direction in function of month; $\mathbf{b}$ percentile rose plots of $\mathrm{SO}_{2}$ concentrations as a function of month

was vehicle emissions from major roads. The levels of $\mathrm{O}_{3}$ were associated with its precursors and especially high in January-March with means of $20 \mathrm{ppb}$ and $45 \mathrm{ppb}$ during lower period of $\mathrm{O}_{3}$ and high period of $\mathrm{O}_{3}$, respectively. The distribution of $\mathrm{SO}_{2}$ was distinguishable in the percentile rose plot and predominantly related with northwesterly and south-westerly winds carrying emissions mainly from the shipping port, along with other minor sources of industrial emissions, power plant emissions and road traffic. This study suggests detail information on emission inventory in urban environment especially from motor vehicles and industrial activities.

\section{Additional files}

Additional file 1. Annual mean air pollutants concentration from 2005 to 2015 .

Additional file 2. Ambient air-quality standard of criteria air pollutants in Malaysia and United States of Environmental Protection Agency.

\section{Abbreviations}

MAAQS: Malaysian Ambient Air Quality Standard; NAAQS: National Ambient Air Quality Standard.

\section{Authors' contributions}

AAAM conceived the research, conducted data processing and analyses, plotted the figures, interpreted the results and wrote the paper. MTL designed the research, interpretation of the results, provided useful advices and suggested valuable revision on the final draft of the paper. NHB wrote the introduction with $\mathrm{MO}$, plotted the study site, described study site and revised the paper format. FA, JXC and $L$ provided useful advice on the draft of the paper. All authors read and approved the final manuscript.

\section{Author details}

${ }^{1}$ School of Environmental and Natural Resource Sciences, Faculty of Science and Technology, Universiti Kebangsaan Malaysia, 43600 Bangi, Selangor, Malaysia. ${ }^{2}$ Centre for Tropical Climate Change System, Institute of Climate Change, Universiti Kebangsaan Malaysia, 43600 Bangi, Selangor, Malaysia.

\section{Acknowledgements}

The authors would like to express their most gratitude to Malaysian Department of the Environment (DOE) for permitting us to use the air-quality data. We gratefully thank Natural Environment Research Council (NERC) Openair project (http://www.openair-project.org/). Special thanks to Dr. Rose Norman for proofreading this manuscript. 


\section{Competing interests}

The authors declare that they have no competing interests.

\section{Availability of data and materials}

Not applicable.

\section{Ethics approval and consent to participate}

Not applicable.

\section{Funding}

Universiti Kebangsaan Malaysia, Research University Grants (AP-2015-010).

\section{Publisher's Note}

Springer Nature remains neutral with regard to jurisdictional claims in published maps and institutional affiliations.

Received: 1 March 2018 Accepted: 31 August 2018

Published online: 11 September 2018

\section{References}

Afroz R, Hassan MN, Ibrahim NA (2003) Review of air pollution and health impacts in Malaysia. Environ Res 92(2):71-77

Ahamad F, Latif MT, Tang R, Juneng L, Dominick D, Juahir H (2014) Variation of surface ozone exceedance around Klang Valley, Malaysia. Atmos Res 139:116-127

Amil N, Latif MT, Khan MF, Mohamad M (2016) Seasonal variability of PM2.5 composition and sources in the Klang Valley urban-industrial environment. Atmos Chem Phys 16:5357-5381

Aouizerats B, Van Der Werf GR, Balasubramanian R, Betha R (2015) Importance of transboundary transport of biomass burning emissions to regional air quality in southeast Asia during a high fire event. Atmos Chem Phys 15(1):363-373

Awang MB, Jaafar AB, Abdullah AM, Ismail MB, Hassan MN, Abdullah R, Johan S, Noor H (2000) Air quality in Malaysia: impacts, management issues and future challenges. Respirology 5(2):183-196

Azmi SZ, Latif MT, Ismail AS, Juneng L, Jemain AA (2010) Trend and status of air quality at three different monitoring stations in the Klang Valley, Malaysia. Air Qual Atmos Health 3(1):53-64

Banan N, Latif MT, Juneng L, Ahamad F (2013) Characteristics of surface ozone concentrations at stations with different backgrounds in the Malaysian Peninsula. Aerosol Air Qual Res 13(3):1090-1106

Blumberg KO, Walsh MP, Pera C (2003) Low-sulfur gasoline \& diesel: the key to lower vehicle emissions. http://www.theicct.org/documents/Low-Sulfu r_Exec_Summ_ICCT_2003.pdf

Butler CD, Whelan J (2018) Air pollution and climate change in Australia: a triple burden. Climate change and air pollution. Springer, Berlin, pp 131-149

Carslaw DC (2015) The Openair manual —open-source tools for analysing air pollution data. Manual for Version 1.1-4, King's College London

Carslaw DC, Ropkins K (2012) Openair — an R package for air quality data analysis. Environ Model Softw 27:52-61

Dominick D, Juahir H, Latif MT, Zain SM, Aris AZ (2012) Spatial assessment of air quality patterns in Malaysia using multivariate analysis. Atmos Environ 60:172-181

Dor F, Moullec YL, Festy B (1995) Exposure of city residents to carbon monoxide and monocyclic aromatic hydrocarbons during commuting trips in the paris metropolitan area. J Air Waste Manage Assoc 45(2):103-110

Fenger J (1999) Urban air quality. Atmos Environ 33:4877-4900

Field RD, Van Der Werf GR, Fanin T, Fetzer EJ, Fuller R, Jethva H, Levy R, Livesey NJ, Luo M, Torres O, Worden HM (2016) Indonesian fire activity and smoke pollution in 2015 show persistent nonlinear sensitivity to El Niño-induced drought. Proc Natl Acad Sci 113(33):9204-9209

Guarieiro LLN, Guarieiro ALN (2013) Vehicle emissions: what will change with use of biofuel? Biofuels-economy, environment and sustainability. InTech

Heil A, Goldammer J (2001) Smoke-haze pollution: a review of the 1997 episode in southeast Asia. Reg Environ Change 2(1):24-37

Hyer EJ, Chew BN (2010) Aerosol transport model evaluation of an extreme smoke episode in southeast Asia. Atmos Environ 44(11):1422-1427
Jang E, Do W, Park G, Kim M, Yoo E (2017) Spatial and temporal variation of urban air pollutants and their concentrations in relation to meteorological conditions at four sites in Busan, South Korea. Atmos Pollut Res 8(1):89-100

Juneng L, Latif MT, Tangang FT, Mansor H (2009) Spatio-temporal characteristics of $\mathrm{PM}_{10}$ concentration across Malaysia. Atmos Environ 43(30):4584-4594

Juneng L, Latif MT, Tangang F (2011) Factors influencing the variations of $\mathrm{PM}_{10}$ aerosol dust in Klang Valley, Malaysia during the summer. Atmos Environ 45(26):4370-4378

Keywood MD, Ayers GP, Gras JL, Boers CP, Leong (2003) Haze in the Klang Valley of Malaysia. Atmos Chem Phys 3(3):591-605

Khan F, Latif MT, Juneng L, Amil N, Mohd Nadzir MS, Syedul Hoque HM (2015) Physicochemical factors and sources of particulate matter at residential urban environment in Kuala Lumpur. J Air Waste Manage Assoc 65(8):958-969

Khan MF, Sulong NA, Latif MT, Nadzir MS, Amil N, Hussain DF, Lee V, Hosaini PN, Shaharom S, Yusoff NA, Hoque HM, Chung JX, Sahani M, Mohd Tahir N, Juneng L, Maulud KNA, Abdullah SMS, Fujii Y, Tohno S, Mizohata A (2016) Comprehensive assessment of PM25 physicochemical properties during the southeast Asia dry season (southwest monsoon). J Geophys Res Atmos 121:589

Kusumaningtyas SDA, Aldrian E (2016) Impact of the June 2013 Riau province Sumatera smoke haze event on regional air pollution. Environ Res Lett 11(7):075007

Lamarque J-F, Bond TC, Eyring V, Granier C, Heil A, Klimont Z, Lee D, Liousse C, Mieville A, Owen B (2010) Historical (1850-2000) gridded anthropogenic and biomass burning emissions of reactive gases and aerosols: methodology and application. Atmos Chem Phys 10(15):7017-7039

Latif MT, Huey LS, Juneng L (2012) Variations of surface ozone concentration across the Klang Valley, Malaysia. Atmos Environ 61:434-445

Latif MT, Othman M, Idris N, Juneng L, Abdullah AM, Hamzah WP, Khan MF, Sulaiman NMN, Jewaratnam J, Aghamohammadi N, Sahani M, Chung JX, Ahamad F, Amil N, Darus M, Varkkey H, Tangang F, Jaafar AB (2018) Impact of regional haze towards air quality in Malaysia: a review. Atmos Environ 177:28-44

Lee $\mathrm{H}-\mathrm{H}$, Bar-Or RZ, Wang C (2017) Biomass burning aerosols and the lowvisibility events in southeast Asia. Atmos Chem Phys 17(2):965-980

Lin C-Y, Hsu H-M, Lee Y, Kuo C, Sheng Y-F, Chu D (2009) A new transport mechanism of biomass burning from Indochina as identified by modeling studies. Atmos Chem Phys 9(20):7901-11

Malaysian Meteorological Department (2017) General Climate of Malaysia. http://www.met.gov.my/web/metmalaysia/climate/generalinformat ion/malaysia. Accessed 9 May 2017

Mayer H (1999) Air pollution in cities. Atmos Environ 33(24):4029-4037

Monks PS, Granier C, Fuzzi S, Stohl A, Williams ML, Akimoto H, Amann M, Baklanov A, Baltensperger U, Bey I, Blake N, Blake RS, Carslaw K, Cooper OR, Dentener F, Fowler D, Fragkou E, Frost GJ, Generoso S, Ginoux P, Grewe V, Guenther A, Hansson HC, Henne S, Hjorth J, Hofzumahaus A, Huntrieser $H$, Isaksen ISA, Jenkin ME, Kaiser J, Kanakidou M, Klimont Z, Kulmala M, Laj P, Lawrence MG, Lee JD, Liousse C, Maione M, Mcfiggans G, Metzger A, Mieville A, Moussiopoulos N, Orlando JJ, O'dowd CD, Palmer PI, Parrish DD, Petzold A, Platt U, Poschl U, Prevot ASH, Reeves CE, Reimann S, Rudich Y, Sellegri K, Steinbrecher R, Simpson D, Ten Brink H, Theloke J, Van Der Werf GR, Vautard R, Vestreng V, Vlachokotas C, Von Glasow R (2009) Atmospheric composition change-global and regional air quality. Atmos Environ 43:5268-5350

Morawska L, Jayaratne E, Mengersen K, Jamriska M, Thomas S (2002) Differences in airborne particle and gaseous concentrations in urban air between weekdays and weekends. Atmos Environ 36(27):4375-4383

Nerriere É, Zmirou-Navier D, Blanchard O, Momas I, Ladner J, Le Moullec Y, Personnaz MB, Lameloise P, Delmas V, Target A, Desqueyroux H (2005) Can we use fixed ambient air monitors to estimate population longterm exposure to air pollutants? The case of spatial variability in the genotox ER study. Environ Res 97:32-42

Noor NM, Yahaya AS, Ramli NA, Luca FA, Abdullah MMAB, Sandu AV (2015) Variation of air pollutant (particulate matter-PM 10 ) in Peninsular Malaysia study in the southwest coast of Peninsular Malaysia. Rev Chim 66(9):1443-1447 
Pereira M, Santos R, Alvim-Ferraz M (2007) Air quality improvements using European environment policies: a case study of $\mathrm{SO}_{2}$ in a coastal region in Portugal. J Toxicol Environ Health Part A 70(3-4):347-351

Rahman SRA, Ismail SNS, Raml MF, Latif MT, Abidin EZ, Praveena SM (2015) The assessment of ambient air pollution trend in Klang Valley, Malaysia. World Environ 5(1):1-11

Reid J, Xian P, Hyer E, Flatau M, Ramirez E, Turk F, Sampson C, Zhang C, Fukada E, Maloney E (2012) Multi-scale meteorological conceptual analysis of observed active fire hotspot activity and smoke optical depth in the maritime continent. Atmos Chem Phys 12(4):2117-2147

Rodríguez MC, Dupont-Courtade L, Oueslati W (2016) Air pollution and urban structure linkages: evidence from european cities. Renew Sustain Energy Rev 53:1-9

Shannon NK, Loretta JM, Miriam EM, Jonathan JB, Patrick SK, Tianjia L, Melissa PS, Ruth SD, Daniel JJ, Joel S, Montira P, Samuel SM (2016) Public health impacts of the severe haze in equatorial asia in SeptemberOctober 2015: demonstration of a new framework for informing fire management strategies to reduce downwind smoke exposure. Environ Res Lett 11(9):094023

Song S-K, Shon Z-H, Kim Y-K, Kang Y-H, Oh I-B, Jung C-H (2010) Influence of ship emissions on ozone concentrations around coastal areas during summer season. Atmos Environ 44(5):713-723

Streets D, Waldhoff S (2000) Present and future emissions of air pollutants in China: $\mathrm{SO}_{2}, \mathrm{NO}_{x}$, and CO. Atmos Environ 34(3):363-374

Streets DG, Bond T, Carmichael G, Fernandes S, Fu Q, He D, Klimont Z, Nelson S, Tsai N, Wang MQ (2003) An inventory of gaseous and primary aerosol emissions in Asia in the year 2000. J Geophys Resh Atmos 108(D21):8809
Tacconi L (2016) Preventing fires and haze in southeast Asia. Nat Clim Change 6(7):640-643

Tangang F, Latif M, Juneng $L$ (2010) The roles of climate variability and climate change on smoke haze occurrences in southeast Asia Region. LSE Ideas, London

Wan Mahiyuddin WR, Sahani M, Aripin R, Latif MT, Thach T-Q, Wong C-M (2013) Short-term effects of daily air pollution on mortality. Atmos Environ 65:69-79

Wang Y, Zhuang G, Sun Y, AN Z (2006) The variation of characteristics and formation mechanisms of aerosols in dust, haze, and clear days in Beijing. Atmos Environ 40:6579-6591

Wang T, Xue L, Brimblecombe P, Lam YF, Li L, Zhang L (2017) Ozone pollution in China: a review of concentrations, meteorological influences, chemical precursors, and effects. Sci Total Environ 575:1582-1596

Yamaji K, Ohara T, Uno I, Tanimoto H, Kurokawa J-I, Akimoto H (2006) Analysis of the seasonal variation of ozone in the boundary layer in east Asia using the community multi-scale air quality model: what controls surface ozone levels over Japan? Atmos Environ 40(10):1856-1868

Yonemura S, Tsuruta H, Kawashima S, Sudo S, Peng LC, Fook LS, Johar Z, Hayashi M (2002) Tropospheric ozone climatology over Peninsular Malaysia from 1992 to 1999. J Geophys Resh Atmos 107(D15):4229

Yoo J-M, Lee Y-R, Kim D, Jeong M-J, Stockwell WR, Kundu PK, Oh S-M, Shin D-B, Lee $S-J$ (2014) New indices for wet scavenging of air pollutants $\left(\mathrm{O}_{3}, \mathrm{CO}\right.$, $\mathrm{NO}_{2}, \mathrm{SO}_{2}$, and $\mathrm{PM}_{10}$ ) by summertime rain. Atmos Environ 82:226-237

Zhang Q, Streets DG, Carmichael GR, He K, Huo H, Kannari A, Klimont Z, Park I, Reddy S, Fu J (2009) Asian emissions in 2006 for the Nasa Intex-B Mission. Atmos Chem Phys 9(14):5131-5153

\section{Submit your manuscript to a SpringerOpen ${ }^{\circ}$ journal and benefit from:}

- Convenient online submission

- Rigorous peer review

- Open access: articles freely available online

- High visibility within the field

Retaining the copyright to your article

Submit your next manuscript at $\boldsymbol{\nabla}$ springeropen.com 